\section{Mikrosatelliten-Instabilität (MSI)}

\section{J. Arnemann}

Abteilung Molekulargenetik, Labor Dr. Wisplinghoff, Köln, Deutschland

\section{Synonym(e) DNA-Instabilität}

Englischer Begriff microsatellite instability

Definition Ein Test auf Mikrosatelliten-Instabilität (MSI) wird i. d. R. an der DNA aus histologischen Präparaten von Tumorproben im Vergleich zur DNA aus gesunden Zellen durchgeführt, um Hinweise auf eine mögliche Störung der DNA-Reparatur zu bekommen.

Beschreibung Ursache oder Begleitung vieler Tumorerkrankungen ist eine Störung des DNA MismatchReparatursystems (MMR, \ Mismatch-Repair-Defizienz), das Fehler bei der mitotischen Zellteilung bzw. Replikation der DNA korrigiert. Eine Störung dieses Systems aufgrund von Mutationen führt zu einer weiteren Anreicherung von Mutationen in der Zelle und vor allem zu einer Beeinträchtigung relevanter Kontrollfunktionen in der Zelle. Ein Effekt ist hierbei die Anhäufung von Fehlern bei der Replikation von Mikrosatelliten-DNA. Als Folge können bei der Abfolge der Short Tandem Repeats (s. \ Short Tandem Repeat (STR)) zahlenmäßige Veränderungen auftreten (Hypermutabilität), die sich bei der kapillarelektrophoretischen Auftrennung und im obligaten Vergleich zu DNA aus gesundem Gewebe oder Blut als neue und zusätzliche Mikrosatelliten-Fragmente darstellen lassen und als Mikrosatelliten-Instabilität (MSI) definiert werden. Das Auftreten neuer MikrosatellitenFragmente ist der stellvertretende Nachweis, dass das Mismatch-Reparatursystem nicht korrekt funktioniert.

Die für die Analyse auf MSI eingesetzten MikrosatellitenMarker wurden international festgelegt und erlauben eine Vergleichbarkeit zwischen den untersuchenden Laboren. Eine besondere Bedeutung hat die MSI-Analyse bei Verdacht auf Vorliegen eines hereditären non-polypösen Kolonkarzinoms (HNPCC; Lynch-Syndrom). Bei positiven Nachweis werden zuerst die am häufigsten betroffenen Reparaturgene MLH1 (ca. $60 \%$ ) und MSH2 (ca. $30 \%$ ), danach die Gene MSH6 und PMS2 durch Sequenzierung und/oder MLPA-Analyse hinsichtlich Mutationen getestet, um das Vorliegen dieser erblichen Tumorerkrankung zu überprüfen.

Einsatzgebiet Tumoranalyse auf Vorliegen von Mutationen im Mismatch-Reparatursystem (MMR).

\section{Literatur}

Gatalica Z et al (2016) High microsatellite instability (MSI-H) colorectal carcinoma: a brief review of predictive biomarkers in the era of personalized medicine. Familial Cancer 15:405-412

Popat S et al (2005) Systematic review of microsatellite instability and colorectal cancer prognosis. Clin Oncol 23:609-618 